http://dx.doi.org/10.15762/ZH.2015.40

ZOFIA ZIELIŃSKA

(Uniwersytet Warszawski)

\title{
POLSKIE TŁUMACZENIA KORESPONDENCJI STANISŁAWA AUGUSTA Z KATARZYNĄ II I NIKITĄ PANINEM Z LAT 1769-1772
}

Słowa kluczowe: epistolografia monarchów, polskie przekłady, konfederacja barska, Czartoryscy, dyplomacja polska i rosyjska, pierwszy rozbiór Rzeczypospolitej

W kodeksie, w którym Stanisław August przechowywał prowadzoną w języku francuskim korespondencję z Katarzyną II i jej ministrem spraw zagranicznych, Nikitą Paninem, znajduje się kilkanaście listów tłumaczonych na język polski ${ }^{1}$. Pochodzą z lat 1769-1772. Przekłady te obejmują zarówno pisma, których autorem był król, jak i odpowiedzi na nie. Ich powstanie wiąże się z konfederacją barską.

Gdy wbrew nadziejom Stanisława Augusta i ambasadora Nikołaja Repnina nie udało się stłumić ruchu barskiego w zarodku, latem 1768 r. rosyjski dyplomata zaczął nakłaniać zarówno króla, jak i Czartoryskich do sformowania antybarskiej rekonfederacji. Monarcha, podobnie jak jego wujowie, których od wiosny $1767 \mathrm{r}$. dzielił z siostrzeńcem duży dystans, postawili warunek: wycofanie przynajmniej części ustawodawstwa sejmu 1767-1768 r. w sprawie dysydentów i gwarancji. Ponieważ Katarzyna odmówiła jakichkolwiek ustępstw, negocjacje zostały przerwane. Wznowiono je po wybuchu w październiku 1768 r. wojny rosyjsko-tureckiej. W jej obliczu uspokojenie Rzeczypospolitej stawało się dla Rosji pilne. Równocześnie doszło do zbliżenia Stanisława Augusta i starych książąt. Na początku grudnia 1768 r. N. Repnin znów wystąpił wobec króla i Czartoryskich z żądaniem sformowania rekonfederacji przeciw Barowi. Miało ją ułatwić „objaśnienie gwarancji”. Petersburg zapewniał w nim, że nie zamierzał ograniczać polskiej suwerenności, ale za tą deklaracją nie tylko nie szły konkrety, lecz przeciwnie - „Objaśnienie” potwierdzało obowiązujący charakter ustaw sejmu 1767-1768 r. z rosyjską gwarancją na czele. Czartoryscy ponownie zatem z rozmów zrezygnowali. Już wówczas formułowali swe żądania szeroko - prócz wycofania ustawodawstwa sejmu „repni-

${ }^{1}$ Jest to kodeks numer 226 z Archiwum Królestwa Polskiego (dalej cyt. AKP) w Archiwum Głównym Akt Dawnych w Warszawie. 
nowskiego" w sprawie dysydentów i gwarancji domagali się rezygnacji przez Rosję także z innych jego ustaw oraz zgody na mediację mocarstw katolickich ${ }^{2}$.

Po wycofaniu się Czartoryskich adresatem rosyjskich nagabywań w sprawie antybarskiej rekonfederacji pozostał król. W pełni podzielając poglądy wujów i współdziałając z nimi, monarcha nie widział szans na antybarski związek bez rosyjskich ustępstw. Swe stanowisko wyjaśnił w obszernym liście do Katarzyny II z 26 I 1769 r. Było to, jak sądzę, pierwsze z serii tłumaczonych na język polski pism, a motywy przekładu można znaleźć w liście króla do polskiego rezydenta w Petersburgu, Jakuba Psarskiego, z 7 X 1769 r. Ów „lettre ostensible” (jego założenia J. Psarski miał dokładnie przedstawić N. Paninowi) ${ }^{3}$ stanowił część ekspedycji wysłanej do Petersburga po Radzie Senatu, obradującej od 30 IX do 6 X 1769 r. Rada zebrała się mimo zabiegów ambasadora Michaiła Wołkonskiego, który usiłował do posiedzenia nie dopuścić, i była wynikiem nowej inicjatywy politycznej króla i Czartoryskich. Próbując wyjść w stosunkach polsko-rosyjskich z bierności, polscy przywódcy zdecydowali się wysłać do imperatorowej poselstwo, w którym prosząc o zgodę na wycofanie gwarancji i równouprawnienia dysydentów, a także na mediację mocarstw, całą winę za napięcie $\mathrm{w}$ stosunkach polsko-rosyjskich zrzucali na brutalność N. Repnina. Sądzili, że pozwoli to Katarzynie II na wycofanie się $\mathrm{z}$ twarzą z dotychczasowej odmowy ustępstw i na przyjęcie w sprawie dysydenckiej i w kwestii gwarancji rozwiązania kompromisowego. Miało ono otworzyć drogę do uspokojenia Rzeczypospolitej. Równocześnie Rada Senatu wyłoniła posłów do europejskich stolic z prośbą o mediację

Rosyjska imperatorowa piórem N. Panina z oburzeniem odrzuciła propozycję. Podkreśliła, że N. Repnin działał zgodnie z jej rozkazami, i uprzedziła, że posel-

\footnotetext{
${ }^{2}$ Podstawowym źródłem informacji na temat czasów barskich pozostaje monografia: Władysław KonopczyŃski, Konfederacja barska, t. 1-2, Warszawa 1991 (wyd. 1: 1936-1938). Najważniejszą edycją źródłową dla okresu do października-listopada 1768 r. jest publikacja korespondencji Stanisława Augusta z Ksawerym Branickim: Konfederacya barska. Korespondencya między Stanisławem Augustem a Ksawerym Branickim, łowczym koronnym w roku 1768, wyd. Ludwik GumPLowicz, Kraków 1872. Od schyłku października 1768 r. głównym źródłem informacji stają się pamiętniki Stanisława Lubomirskiego, zob. Stanisław Lubomirski, Pamiętniki, wyd. Władysław Konopczyński, Lwów 1925. Żądanie mediacji mocarstw pojawia się u S. Lubomirskiego po raz pierwszy pod datą 24 XI 1768 r. (S. Lubomirski, op.cit., s. 14).

${ }^{3}$ Król pisał o tym wprost w równoczesnym liście do rosyjskiego ministra: „kiedy Waszmość Pan usłyszysz, co rezydent mój będzie miał honor mówić Waszmość Panu z tej okoliczności według tego, com pisał do niego w tej materyi [...]”, AKP, nr 226, k. 155v. List króla J. Psarski wręczył zresztą N. Paninowi, co ten potwierdził w instrukcji dla następcy N. Repnina, Michaiła Wołkonskiego, z 31 X/11 XI 1769 r., Сборник Императорского Русского исторического общества (dalej суt. СИРИО), вып. 87, Санкт-Петербург 1893, s. 513.

${ }^{4}$ Przebieg obrad senatorów omówił W. Konopczyński, zob. idem, Konfederacja barska, t. 1, s. 273-276. Szczegóły stanowiska M. Wołkonskiego znamy z pracy: Николай Ф. Дубровин, Накануне первого раздела Польши - 1770 г. Ро рукописным донесениям князя М.Н. Волконского, Вестник Европы, т. 6: 1868, s. 582-584.
} 
stwa nie przyjmie ${ }^{5}$. Inicjatywa króla i Czartoryskich okazała się więc chybiona, strona polska skazana była na trwanie w bierności.

We wspomnianym liście Stanisława Augusta do J. Psarskiego znalazł się fragment, który na temat genezy powstania polskich przekładów omawianej korespondencji zawiera ważną wskazówkę: „List mój do imperatorowy, który starać się Waszmość Pan będziesz, aby jej doszedł jak najprędzej [...], zawiera treść tego, co Waszmość Pan masz mówić obszerniej w tej okoliczności. Najistotniejszym jest dobrze pokazać dworowi rosyjskiemu konieczną potrzebę, w której się znajdowałem, zwołać Radę Senatu. A ta zasadza się na powszechnej niecierpliwości in publico w Polszcze i na wymówkach, które mi czyniono ze wszech stron [...], iż jeżeli zostawać dalej będę w nieczynności, naród coraz bardziej wyperswaduje sobie, że nie ma niczego się spodziewać ode mnie, a zatym że mu nie zostaje, tylko myślić o sobie, choćby też z hazardem korony mojej i nawet życia mego. [...]

Jest rzecz oczywista, że naród dlatego tylko źle mi życzy, że mię nie zna. Ażeby go wyprowadzić $\mathrm{z}$ omyłki, starałem się puścić w poszród narodu, bez wielkiego jednak rozgłoszenia, wiadomości przynajmniej ogólne o tym, com nie przestał czynić dla niego sekretnie [wszystkie pogrubienia moje - Z.Z.]. [...] Odpowiadają mi ze wszech stron: nie dosyć na tym. Gdybyś królu nie był Polakiem, gdybyś nie czynił, tylko przez ludzkość i litość dla Polski lub też przez roztropną gorliwość dla Rossyi, dosyć by było mówić i pisać jakoś dotychczas czynił. Ale jesteś Polakiem i królem polskim. Trzeba, ażebyś przez akt autentyczny dał dowód, że wszystko się stało mimo wolę twoję na ostatnim sejmie. Po takowym chyba dowodzie naród przestanie rozumieć, że jesteś autorem srogości i nieszczęśliwości, które więcej od dwóch lat ponosi. Naówczas dopiero zacznie cię słuchać i mieć ufność w tobie, że może powierzyć w ręce twoje interesów swoich względem Rosyi nawet”.6.

Stanisław August rozpoczynał zacytowany fragment od usprawiedliwień z powodu zwołania Rady Senatu. Mówiono na niej dużo o brutalnych postępkach Repnina, pokazując, że to nie król, a rosyjski ambasador był autorem "gwałtów” z lat 1767-1768. Ten aspekt monarcha wprawdzie w liście do J. Psarskiego przemilczał, ale intencja Rady - zdjęcia z władcy odium za wydarzenia sejmu „repninowskiego" - była dla Petersburga jasna w świetle raportów M. Wołkonskiego ${ }^{7}$. Monarcha podkreślał, że chodziło o pokazanie społeczeństwu drogi wyjścia z impasu, w jakim Polska się znalazła, i przekonanie go, że władca potrafi je tą drogą poprowadzić. Aktywna postawa króla miała potwierdzić jego przywództwo i utrudnić działania osób zmierzających do detronizacji czy wręcz do zamachu na życie monarchy.

Antykrólewskie ostrze konfederacji barskiej Stanisław August uważał za tragiczną pomyłkę. Jego wrogom, przywódcom konfederacji radomskiej, którzy następnie wywołali barskie powstanie, udało się wmówić Polakom, że to nie oni

${ }^{5}$ Panin do Stanisława Augusta w imieniu Katarzyny II, 31 X [11 XI] 1769 r., СИРИО, вып. 87, s. $523-529$.

${ }^{6}$ Stanisław August do J. Psarskiego, AKP, nr 226, k. 156v, 158-158v.

${ }^{7}$ Zob. dzieła powołane w przyp. 4. 
prosili Rosję o równouprawnienie dysydentów i o gwarancję ustrojową, lecz że wszystkiemu winny był monarcha ${ }^{8}$. O potrzebie zwalczania tych oszczerstw i przekonania społeczeństwa, że król nie reprezentował interesów Rosji, lecz własnego narodu, którego dobra, podobnie jak odrodzenia państwa pragnął, wielokrotnie była mowa w korespondencji Stanisława Augusta z Ksawerym Branickim9. W tym samym też celu król zaczął rozpowszechniać „wiadomości przynajmniej ogólne o tym, com nie przestał czynić dla niego [narodu] sekretnie". Jak wynika z listu do J. Psarskiego, nie przyniosło to oczekiwanych efektów. Dlatego potrzebny był czyn („akt autentyczny”, to jest Rada Senatu), który przekonałby Polaków, że działania N. Repnina na sejmie 1767-1768 r. szły wbrew woli króla („mimo wolę twoję), który nie był też ich inspiratorem („naród przestanie rozumieć, że jesteś autorem srogości i nieszczęśliwości, które więcej od dwóch lat ponosi”). Wyprowadzenie społeczeństwa z błędnych mniemań, odzyskanie jego szacunku i zaufania stanowiło warunek pociągnięcia go przez króla ku pożądanej przez Rosję pacyfikacji. Ten sam cel Rady Senatu - „odzyskania ufności i miłości ludu mego” jako czynników niezbędnych dla uspokojenia kraju - Stanisław August wskazał zresztą w pisanym równocześnie liście do Katarzyny II $^{10}$.

W polskich tłumaczeniach korespondencji z Katarzyną II i N. Paninem upatrywałabym instrumentów, za pomocą których król chciał „puścić w poszród narodu [...] wiadomości przynajmniej ogólne o tym, com nie przestał czynić dla niego sekretnie”. Czy rzeczywiście owe przekłady zostały „puszczone w naród”, można wątpić. Sprawa była delikatna, zważywszy, że korespondencja monarchów uchodziła za rzecz poufną. Po to, by z tym, co pisał do Katarzyny II, i z jej odpowiedziami zaznajomić swych najbliższych współpracowników, w tym Czartoryskich, Stanisław August nie potrzebował sporządzać tłumaczeń. Wersja polska przeznaczona była dla niewładającej językiem francuskim średniej i drobniejszej szlachty prowincjonalnej, zapełniającej barskie szeregi ze szczerego, choć naiwnego patriotyzmu ${ }^{11}$. Czy próba przekonania barzan do króla przez ujawnienie jego korespondencji

\footnotetext{
${ }^{8}$ Stanisław August pisał o tym m.in. do swej paryskiej „mamy”, Marie Thérèse Geoffrin, $21 \mathrm{~V}$ 1768 r.: „C'est surtout depuis que des personnes de cette famille [Potoccy] ont levé le masque que le nombre des confédérés a grossi, sans se souvenir que ces mêmes Potocki ont appelé les Russes, il y a un an, pour établir non seulement les dissidents, mais encore la garantie russe contre la pluralité, lorsqu'ils ont espéré par là me renverser", Correspondance inédite de Stanislas-Auguste Poniatowski et de Madame Geoffrin, par Charles DE Moư̈, Paris 1875, s. 335-336.

${ }^{9}$ K. Branicki do Stanisława Augusta, 4 i 11 VI, 20 VIII 1768 r.; Stanisław August do K. Branickiego, 9 i 20 VI 1768 r., Konfederacya barska. Korespondencya, s. 7-8, 11, 16, 19-20, 79.

${ }^{10}$ Stanisław August do Katarzyny II, 7 X 1769 r., AKP, nr 226, k. 151-152 (tekst francuski); polskie tłumaczenie - ibid., k. 154-155.

${ }^{11} \mathrm{O}$ motywach szlachty - chęci walki o wiarę i wolność, które przeciwstawiał nieczystym intencjom magnackich szefów konfederacji - król pisał kilkakrotnie do pani Geoffrin, powtórzył też ową opinię w Suum cuique. Zob. Stanisław August do M.T. Geoffrin, 9 IV, 1 i 21 V, 1 VI 1768 r., Correspondance inédite, s. 327-328, 335-336; „Roku 69 rozszerzył sie ogień, w mocnej i sprawiedliwej fomentacyi był naród, ranionym się czuł, szukał lekarstwa [...]. Nietrudno było poruszyć naród, bo go uczucia własne, sprawiedliwe dolegania chciwym czyniły brać się do ratunku swej sławy”, Suum cuique, [s.l., s.a.], brak pag.
} 
z imperatorową warta była ryzyka narażenia się na gniew rosyjskiej władczyni? Takie pytanie Stanisław August musiał sobie postawić. I, jak sądzę, odpowiedział na nie negatywnie. Jeśli by bowiem owe tłumaczenia rozpowszechniał, powinny się zachować tego ślady. Tymczasem polskich przekładów korespondencji Warszawy z Petersburgiem nie ma nigdzie poza ich brulionami w kodeksie z królewskiego archiwum. Zapewne więc nie były rozpowszechniane. Mimo to dostarczają dowodów, jakimi argumentami Stanisław August chciał do siebie „naród” przekonać. Aby argumenty te poznać, wypadnie bliżej zająć się treścią przetłumaczonych na język polski listów.

Najważniejszym z nich i pierwszym chronologicznie był list do Katarzyny II z 26 I 1769 r. ${ }^{12}$ Jego leitmotiv stanowiło twierdzenie, że antybarska rekonfederacja, której sformowania żądał od króla N. Repnin, nie była możliwa bez rosyjskich ustępstw w sprawie gwarancji i dysydentów. Argumentację król zaczynał od przypomnienia, że wielokrotnie szczegółowo przedstawiał N. Repninowi to, co uważał w jego poczynaniach za szkodliwe dla Polski i dla siebie ${ }^{13}$. W ostrzeżeniach tych, zwłaszcza w odniesieniu do kwestii dysydenckiej potwierdzonych przez późniejsze wydarzenia, ambasador i jego mocodawcy dopatrywali się jednak złej woli polskiego wład$\mathrm{cy}^{14}$. Lojalność swej postawy przeciwstawiał monarcha działaniom przywódców barskich, którzy pobudzali przeciw Katarzynie II jej nieprzyjaciół (czytaj: Turcję) i wchodzili we wrogie Rosji porozumienia zagraniczne (zapewne: $z$ Turcją i Francją), a dla których w ich wcieleniu radomskim wymagano od króla szkodliwych dla kraju awansów ${ }^{15}$. Ceną, jaką zapłacił monarcha za postępowanie rosyjskiego ambasadora, stała się niechęć, a nawet nienawiść większości narodu do władcy. Polacy, nie zdając sobie bowiem sprawy ze sporów, jakie toczył on z N. Repninem (dodajmy to, czego w liście nie było: a widząc wsparcie, jakiego podczas sejmu 1767-1768 r. król udzielał ambasadorowi w sprawie dysydenckiej), uznali monarchę za inspiratora gwarancji i równouprawnienia innowierców. Ulegli w tym propagandzie przywódców konfederacji radomskiej, którzy przeszedłszy do Baru, zainteresowani zatarciem własnego udziału w przeforsowaniu gwarancji i równouprawnienia in-

\footnotetext{
12 Tekst francuski: AKP, nr 226, k. 116-124 (minuta ręki sekretarza z korektami króla); kopia sekretarska w: Biblioteka Czartoryskich w Krakowie (dalej cyt. Bibl. Czart.), sygn. 2098, s. 505-520; oryginał w Moskwie: Архив внешней политики Российской империи, фонд 79 (Сношения России с Польшей), оп. 6, но. 79, k. 1-4; wersja polska w: AKP, nr 226, k. 125-130.

${ }^{13}$ „Cokolwiek w tych rzeczach, które się tutaj od więcej dwóch lat działy, zdało mi się być szkodliwym Polszcze, mnie osobiście i, według mego pojęcia, samejże Waszej Cesarskiej Mości [dalej: WCMości - Z.Z.], przekładałem posłowi jej pełnomocnemu patryjotycznie, otwarcie, codziennie i z najusilniejszą dokładnością", AKP, nr 226, k. 125-125v.

14 „Pamiętam, że gdym przed dwoma laty remonstrował niezmierną trudność interesu dysydenckiego, innym powodom przypisano naówczas to, com mówił jedynie z znajomości umysłów ziomków moich. Usprawiedliwiają mnie teraźniejsze dzieje”, ibid., k. 127-127v.

${ }^{15}$ „Alem nigdy przeciw WCMości nieprzyjaciół nie wzburzał, w żaden związek nie wchodziłem polityczny mimo WCMość, wzorem tylu innych, dla których jednak wymagano na mnie dogadzania tak szczerbiące Rzeczpospolitą i mnie samego", ibid., k. 125v.
} 
nowierców, obarczyli za nie winą króla ${ }^{16}$. Skuteczność tej propagandy ułatwiał fakt, że rosyjska przemoc, widoczna zarówno w Radomiu, jak i na sejmie repninowskim, usprawiedliwiała w oczach ogółu działania radomskich tuzów ${ }^{17}$.

Jako powód tajenia przed społeczeństwem swych sporów z N. Repninem król wskazywał przewidywane konsekwencje ewentualnej wiedzy: „gdyby byli o nich wiedzieli obywatele, ostrzejsze by zapewne stało się ich sprzeciwienie, a widziałem urezolwowane ostatnie nieszczęścia na tych, którzy by się sprzeciwili”. Nie wspominając wprost o brutalnych postępkach ambasadora, Stanisław August czynił do nich niedwuznaczną aluzję. Zwraca uwagę poczucie odpowiedzialności króla za współobywateli, których nie chciał narażać na rosyjskie represje. Podkreślał natomiast własne próby krzyżowania rosyjskich działań do czasu, aż się zorientował w bezowocności, a nawet szkodliwości oporu, prowadzącego „do jeszcze gorszego ojczyzny mojej uszkodzenia"18. Zważywszy, że kapitulacja Stanisława Augusta nastąpiła między połową marca i końcem kwietnia 1767 r. (terminem prekluzyjnym było przyjęcie 28 kwietnia, na oficjalnej audiencji, deputatów rokoszowych konfederacji dysydenckich, i tym samym zalegalizowanie ich związków) ${ }^{19}$, można się domyślać, że owo „większe uszkodzenie” to przesądzone już wówczas powstanie malkontenckiej konfederacji w Wielkim Księstwie Litewskim, a więc rozstrzygający krok do powstania związku generalnego w Radomiu.

Przypomniawszy ciągłe odradzanie się konfederacji w różnych częściach kraju, król konkludował, że wobec powszechnego niezadowolenia społeczeństwa próba sformowania antybarskiej rekonfederacji bez rosyjskich ustępstw w sprawie gwarancji i dysydentów prowadziłaby do katastrofy, to jest powszechnego wybuchu w całej Polsce. Warunkiem uspokojenia kraju była zatem gotowość Katarzyny II do kompromisu w obu wymienionych kwestiach: „jeszcze i dalej powinienem remonstrować WCMości, że od niej dependuje i że jej samej mocno na tym należy uspokoić Polskę, mnie przywrócić miłość kraju, a przez to położyć mnie w stanie być istotnie użytecznym WCMości”20. Ten wniosek król powtarzał w zakończeniu listu:

\footnotetext{
16 „Stąd właśnie przyczyna oddalenia ode mnie i (co mi jest najboleśniejszym) nawet nienawiści przeciw mnie większej narodu części, która nie wiedząc o ustawnych repezentacyjach moich przeciw temu wszystkiemu, co się jej zda uciążliwym, mieni mnie być przyczyną tych rzeczy, których prawdziwemi autorami są ci, kilku panów polskich, którzy je wprawdzie dla swoich końców rozpoczęli, a teraz chcąc siebie wywinić przed narodem, mają w tym interes obłudnie rozsiewać, że to ja żądałem gwarancyi i porównania dysydentów z katolikami in civilibus", ibid.

${ }^{17}$ „Jeźli im kto mówi: ale konfederacyja radomska wysłała posłów do Moskwy, którzy o to prosili, co się na sejmie stało, oni odpowiedają: nie zapomnieliśmy sposobów, któremi i konfederacyją, i sejm determinowano", ibid., k. 127.

${ }^{18}$ „Tych zaś przeszkód, które sam osobiście imprezom przedsięwziętym czynić zdołałem, wtedym dopiero poprzestał, gdy mi pokazano gotowość przez insze drogi do jeszcze gorszego ojczyzny mojej uszkodzenia", ibid., k. 126.

${ }^{19}$ Królewską drogę do kapitulacji, to jest do wyboru „mniejszego zła” i nawiązania współpracy z N. Repninem, znakomicie ilustrują trzy listy monarchy do M.T. Geoffrin: z 11 i 20 III oraz z 22 IV 1767 r., Correspondance inédite, s. 275-281.

${ }^{20} \mathrm{AKP}, \mathrm{nr} 226, \mathrm{k} .127 \mathrm{v}$.
} 
„jedne jest lekarstwo, a te w ręku twoich, Najjaśniejsza Pani. Śmiem ufać, że nam go dozwolisz [...], że [...] dogadzając naszej proźbie, mnie przed narodem pozwalając tej zasługi, żem to wyprosił, razem byś mnie dała sposób uspokojenia narodu"21.

Obok tego zasadniczego wątku monarcha skarżył się na rujnowanie kraju przez rosyjskie wojska. „Handel przerwany, i co każdy posesor cierpi od przechodów i bawienia tylu żołnierstwa”. Wojska te „nie powinny być karmione przez obywateli", nie powinny krzywdzić tych, którzy z Barem nie mieli nic wspólnego, nie powinny grabić majątków, ogałacać z dobytków i palić miast, wreszcie płacić fałszywą monetą. „Korpus Kadetów, już do połowy zmniejszony, wkrótce i w tej liczbie nie będzie mógł być utrzymany", mimo zasiłku finansowego, jakiego na ten cel użyczyła monarsze rosyjska władczyni. „Mennica tylko co nie ustawa [...]. Jest to wielką dla całego kraju szkodliwością", najbardziej dolegliwą dla samego króla, ponoszącego największe koszty reformy monetarnej. Apelując do Katarzyny II o ustępstwa, które pozwoliłyby Polskę uspokoić, Stanisław August kończył ostrzeżeniem, że ewentualna odmowa, która przyśpieszyłaby jego upadek, będzie stratą także dla imperatorowej - „ktokolwiek by na moim osiadł miejscu nie będzie ci tak szczerze jak ja przywiązanym"22.

W liście jest szereg komplementów czy wręcz pochlebstw pod adresem Katarzyny II, ale nie przesłaniają one twardego politycznego żądania, jakie autor pisma kierował do jego adresatki. Słusznie więc Władysław Konopczyński stwierdzał, że mamy do czynienia $\mathrm{z}$ tekstem pisanym suaviter in modo, fortiter in re, choć nieco na wyrost uznał w jego treści „spowite w atłasową mowę Poniatowskiego diamentowe postulaty Zamoyskiego i Czartoryskich"23. W innym miejscu próbowałam wykazać, że uznanie Stanisława Augusta wyłącznie za wykonawcę myśli przywódców „Familii”, nie zaś za autora pisma w pełnym tego słowa znaczeniu, nie ma za sobą żadnych argumentów ${ }^{24}$. Dla tematu podejmowanych tu rozważań jest to jednak sprawa dalszorzędna.

Bardziej istotne jest uściślenie tezy, że list ze stycznia 1769 r. był pierwszym $\mathrm{z}$ tłumaczonych. W naszym kodeksie znajduje się bowiem polski przekład pism o dwa lata wcześniejszych - listu króla do imperatorowej z 5 X 1766 r. oraz odpowiedzi nań rosyjskiej władczyni ${ }^{25}$. W piśmie wysłanym w przededniu rozpoczęcia obrad sejmu 1766 r. Stanisław August prosił Katarzynę II o wycofanie żąda-

${ }^{21}$ Ibid., k. 129v.

${ }^{22}$ Ibid., k. 128v-129, 130

${ }^{23}$ W. KonopCZYŃski, Konfederacja barska, t. 1, s. 176.

${ }^{24}$ Zofia Zielińska, Portret Stanisława Augusta $w$ „Konfederacji barskiej” Władysława Konopczyńskiego, [in:] Władysław Konopczyński jako badacz dziejów XVIII wieku, red. Zofia ZIELIŃsKA, Wojciech Kriegseisen, Warszawa 2014, s. 152-154.

${ }^{25}$ Stanisław August do Katarzyny II, 5 X 1766 r., AKP, nr 226, k. 68-71v (tekst francuski); k. $72-$ 74v (przekład polski); kopia sekretarska w: Bibl. Czart., sygn. 798, s. 739-742; drugi egzemplarz: ibid., s. 1141-1153. List publikowany w: Stanislas Auguste, Mémoires, éd. Anna Grześkowiak-Krwawicz et Dominique Triaire, Paris 2012 (dalej cyt. Mémoires), s. 322-324; Katarzyna II do Stanisława Augusta, 6 [17] X 1766 r., СИРИО, вып. 67, Санкт-Петербург 1889, s. 149-155 (tekst francuski); AKP, nr 226, k. 79-83v (przekład polski). 
nia politycznego równouprawnienia dysydentów. Listowi przypisywał dużą wagę, tuż po sejmie pisał do swej francuskiej „mamy”, że wysyłając go, zrobił dla wiary więcej niż popisujący się katolicką gorliwością biskup Kajetan Sołtyk ${ }^{26}$. Zaryzykowałabym jednak tezę, że list z $1766 \mathrm{r}$. został przetłumaczony dopiero w czasach barskich jako ilustracja tego, co król czynił dla narodu „sekretnie” w najbardziej poruszającej szlacheckie umysły sprawie dysydenckiej. Pismo z 1766 r. należałoby traktować jako załącznik do listu ze stycznia 1769 r. Rosyjska władczyni, odpowiadając w 1766 r. na prośbę polskiego monarchy o zmniejszenie zakresu żądań w sprawie dysydenckiej, nie zadawała sobie zbytniego trudu argumentowania. Zapewniała, że jej prodysydenckie żądania wynikały z poczucia sprawiedliwości dla bezprawnie uciśnionych w Polsce innowierców. Uprzedzała, że nie zadowoli się zapewnieniem im tylko tolerancji religijnej, którą i tak mają, groziła, że w razie potrzeby swe żądania przeforsuje siłą. Zarzucała królowi słabość polityczną przejawioną $\mathrm{w}$ braku gotowości do kompromisu, nie zamykała jednak jeszcze doń drogi. List imperatorowej, wystawiony 17 X 1766 r., dotarł do Warszawy jednak za późno, by zaważyć na sprawie dysydenckiej - w sejmie rozgorzała bowiem walka w kwestii dla Rosji o wiele ważniejszej, o byt liberum veto ${ }^{27}$.

Wróćmy jednak do listu ze stycznia 1769 r. Król otrzymał nań odpowiedź zarówno od Katarzyny II, jak i od N. Panina. Obszerna odpowiedź rosyjskiego ministra, przełożona na język polski, zawierała tę część argumentów, których nie chciała firmować imperatorowa.

W liście, który skierowała do Stanisława Augusta (a odpisywała dopiero dwa miesiące po otrzymaniu pisma królewskiego), Katarzyna II ponownie odmawiała jakichkolwiek ustępstw zarówno w kwestii dysydenckiej, jak i w sprawie gwarancji. Swą interwencję w Rzeczypospolitej na rzecz innowierców uznawała za wsparcie sprawiedliwej sprawy uciśnionych, a więc przejaw humanitaryzmu, gwarancję określała jako „obowiązek dla narodu, zaciągniony przez przyjaźń daleką od wszelkich osobistych zysków", a utrzymanie ustawodawstwa sejmu 1767-1768 r. za swój „obowiązek dostojeństwa”. Podając w wątpliwość przekonanie Stanisława Augusta, że ustępstwa w sprawie gwarancji i dysydentów stanowiły warunek uspokojenia Polski, aluzyjnie wskazywała, że przyczyną barskiego buntu nie były owe dwie kwestie, lecz sprawa zupełnie inna, a zarówno uspokojenie Rzeczypospolitej, jak i bezpieczeństwo jej władcy zależały od powodzenia rosyjskiego oręża ${ }^{28}$.

Wykład na temat brutalnej rzeczywistości imperatorowa pozostawiła N. Paninowi ${ }^{29}$. Negując rozeznanie Stanisława Augusta, że uspokojenie Polski wymagało

\footnotetext{
${ }^{26}$ Stanisław August do pani M.T. Geoffrin, 10 XII 1766 r., Correspondance inédite, s. 261.

${ }^{27}$ Szerszy kontekst pisma z 5 X 1766 r. przedstawiono w: Maria Cecylia ŁuBIEŃskA, Sprawa dysydencka 1764-1766, Kraków-Warszawa 1911, s. 102-104; Zofia Zielińska, Polska w okowach „systemu pótnocnego" 1763-1766, Kraków 2012, s. 535, 539-541.

${ }^{28}$ Katarzyna II do Stanisława Augusta, 26 III [6 IV] 1769 r., oryginał francuski w: СИРИО, вып. 87, s. 362-367; tłumaczenie polskie w: AKP, nr 226, k. 137-142.

${ }^{29}$ N. Panin do Stanisława Augusta, 26 III [6 IV] 1769 r., oryginał francuski w: СИРИО, вып. 87, s. 368-370; polskie tłumaczenie w: AKP, nr 226, k. 461-462v.
} 
ustępstw ze strony Katarzyny II, minister wskazywał, że główną przyczyną wybuchu barskiego buntu była dążność Polaków do pozbycia się z tronu Stanisława Augusta: „Bądź Wasza Królewska Mość pewnym, że nie idzie tu o to, ażeby dysydenci mieli mniej lub więcej bytu w stanie cywilnym, ale że wszystko jest directe obrócone przeciw jego osobie. Niechby tylko jedne słowo rzekła imperatorowa, a wraz i zachowałaby w całości wszystkie punkta ustanowione na ostatnim sejmie, i w Polszcze broń złożona byłaby, i uspokoiłoby się wszystko. Między wszystkiemi podpalaczami najzajadlejszemi, między wszystkiemi pryncypałami rozmaitych fakcyj żadnego nie masz, który by się nie poddał we dwudziestu czterech godzinach i na te kondycyje, skoro by widzieli, że imperatorowa zezwala na sakryfikowanie korony Waszej Królewskiej Mości”. Wniosek był oczywisty: „z przyjaciółmi swemi sądzić powinieneś Wasza Królewska Mość o sytuacyi swojej, przeświadczyć ich i zniewolić do czynienia to, czego bezpieczeństwo jego wyciąga, łącząc jawnie i nieodwłocznie swoje i przyjaciół swoich usiłowania według zamysłów Najjaśniejszej Imperatorowy”. Było to wezwanie do bezwarunkowej uległości wobec rosyjskich żądań. Połączone z odmową ustępstw ze strony Petersburga skazywało Warszawę na trwanie w bierności.

Próba wyjścia z niej w postaci decyzji Rady Senatu z września-października 1769 r. znów zaowocowała polskimi przekładami królewskiej korespondencji. Tłumaczenie obejmowało listy króla do Katarzyny II i Panina, a najbardziej instruktywna była pisana po polsku depesza polskiego władcy do rezydenta J. Psarskiego. Wobec Katarzyny II monarcha podkreślał, że wyznaczone przez Radę Senatu poselstwo do Petersburga stanowiło drogę „do odzyskania ufności i miłości ludu mego”, z kolei zaś „ufność i miłość narodowa są jedynym szrodkiem, przez który bym mógł nakłonić umysły do przedsięwzięcia zbawiennych kroków ku uspokojeniu" ${ }^{30}$. Nowe środki miały więc realizować cele wskazane wcześniej - odzyskanie przez Stanisława Augusta szacunku i zaufania narodu, warunkujących szanse na oczekiwaną przez Rosję pacyfikację. Przetłumaczony na język polski list do N. Panina prócz prośby o wsparcie królewskich postulatów wobec imperatorowej zawierał zapowiedź szerszego ich przedstawienia przez J. Psarskiego ${ }^{31}$.

List polskiego władcy do rezydenta już po części znamy. Poza tym, co o jego treści pisałam wyżej, zawierał on przykłady świadczące o dążeniu barzan do detronizacji, a nawet fizycznego ataku na monarchę, obronę Czartoryskich przed uprzedzeniami wobec nich Petersburga, który przywódców „Familii” obwiniał o kierowanie króla na zgubną drogę, wykład racji wysłania posłów do mocarstw zarówno innowierczych, jak i katolickich („że by to zapewne pomnożyło bardziej nieufność narodową, gdyby wysłano do potencyj dysydenckich, nie wysławszy do katolickich"), wreszcie ponowienie czynionej już wielokrotnie prośby o wyprowadzenie

${ }^{30}$ Stanisław August do Katarzyny II, 7 X 1769 r., AKP, nr 226, k. 151-152 (tekst francuski); k. 154-155 (tekst polski).

${ }^{31}$ Stanisław August do N. Panina, 7 X 1769 r., ibid., k. 153-153v (kopia sekretarska); k. 464-464v (minuta ręki króla); k. 155v-156 (polskie tłumaczenie). 
z Rzeczypospolitej rosyjskich wojsk („bawienie onych stawszy się tak przykre dla narodu, że ich przytomność czyni jednę z pryncypalnych skarg narodu") $)^{32}$.

Decyzje jesiennej Rady Senatu oburzyły Katarzynę II (rozumiemy dlaczego - mediacja mocarstw dowodziłaby wszak, że Rosja przestała dysponować wyłączną „influencją" w Rzeczypospolitej), odpowiedź osobistą na list króla uznała za uwłaczającą jej godności. Ripostę wystosował więc N. Panin, pisząc w imieniu władczyni, a osobno od siebie. Oba listy miały napełnić króla strachem co do skutków drogi, na jaką wszedł za radą wyklętych odtąd w Petersburgu Czartoryskich; M. Wołkonski winien był przekonywać króla o „пагубных следсвиях легкомыслия, непостоянства и безразсудности его” і „его [króla] привесть чрез то в болшее размышление и тревогу"33. Jest zrozumiałe, że tłumaczeń tych odpowiedzi w naszym zbiorze nie ma.

Niefortunne doświadczenia z jesieni 1769 r. nie położyły kresu dalszym przekładom królewskiej korespondencji. Dnia 21 II 1770 r. Stanisław August odezwał się do imperatorowej ponownie i zarówno pismo króla, jak i otrzymana na nie odpowiedź zostały przetłumaczone na język polski ${ }^{34}$. List swój monarcha zamieścił ponadto w pamiętnikach, więc przykładał do niego szczególną wagę. Zaczynał od stwierdzenia, że nie wie, jakich konkretów oczekiwała od niego Rosja, po czym ponawiał stanowisko wyrażone wcześniej: „Życzę, ażeby Polska była uspokojoną prędko i gruntownie. To być nie może, jeżeli naród nie będzie ukontentowanym. Naród nie może być ukontentowanym, jeżeli sam przez się czynić nie będzie w stanach zgromadzony, i prawnie. To ażeby nastąpiło, trzeba sejmu i przedsejmowych sejmików. Złożenie sejmików podobne być nie może, aż wtenczas, kiedy ogólność narodu będzie do tego nakłoniona pomyślnie. Ta skłonność wyniknąć nie może, tylko z nadziei otrzymania tego, czego naród najbardziej żąda"35. Zasadności rozpoznania, że bez ustępstw imperatorowej nie było szans na pacyfikację, miała dowodzić przywołana przez króla nieudana próba wywołania antybarskiej rekonfederacji - chodziło zapewne o chybione poczynania „Rady Patriotycznej”, jaką po zwątpieniu w Czartoryskich zgromadził wokół siebie M. Wołkonski ${ }^{36}$. Stanisław August skarżył się dalej na nadużycia rosyjskich wojsk. Uprzedzał, że skutkiem ich grabieży i bezwzględności może się stać głód ${ }^{37}$, ostrzegał, że uciski rosyjskiej armii nie przyśpieszą kapitulacji Polaków, a tylko wzmocnią determinację walczących,

${ }^{32}$ Stanisław August do J. Psarskiego, 7 X 1769 r. , ibid., k. 156v-161 (tylko wersja polska).

${ }^{33}$ N. Panin do M. Wołkonskiego, 31 X [11 ХІ] 1769 r., СИРИО, вып. 87, s. 513-516.

${ }^{34}$ Stanisław August do Katarzyny II, 21 II 1770 r., AKP, nr 226, k. 163-164v (wersja francuska); k. 165-169v (przekład polski); publikacja w: Mémoires, s. 385-387.

${ }^{35}$ AKP, nr 226, k. 166.

${ }^{36} \mathrm{Na}$ temat „Rady Patriotycznej” zob. W. KonopCzyński, Konfederacja barska, t. 1, s. 295-297; Н.Ф. Дубровин, ор.cit., s. 567-572.

37 „Trzecia część pól naszych w najżyźniejszych województwach nie jest zasiana, gdy wszystkie zboża do ostatniego ziarna pozabierano, gdy bydlęta zdatne do rolnictwa wzięte na konsumpcyją wojsk lub upadły w ustawicznych przewozach magazynów odległych o trzydzieści, pięćdziesiąt aż do siedmiudziesiąt mil niemieckich. Dziesiątej części nawet za to wszystko nie zapłacono", AKP, nr 226, k. $167 \mathrm{v}$. 
że wreszcie - na co wskazywały losy konfederacji radomskiej - trwałego pokoju nie da się wprowadzić za pomocą bagnetów. Pismo kończyło się prośbą o zgodę Katarzyny na mediację mocarstw katolickich ${ }^{38}$.

Odpowiedź nie pozostawiała złudzeń. Imperatorowa wyrażała żal, że król nie przestał ufać Czartoryskim i kierować się ich zgubnymi wskazówkami („nie mogłam inaczej dowiedzieć się, jak z dotkliwym żalem, że jego umysł i rzetelność nie ustają być na złe zażywanemi przez zdradę i skryty cel ambicyj tych, którym Wasza Królewska Mość zupełnie zaufałeś"), mediację mocarstw katolickich wykluczała, a Czartoryskim jako inspiratorom tego pomysłu przypisywała intencję „powiększenia teraźniejszych rozterków przez przeciwność interesów, dla których oni chcą wystawić ojczyznę na niebezpieczeństwo"39. Odpowiedź ta powstała w okresie, gdy nad Newą wypracowywano nową koncepcję polityczną wobec Rzeczypospolitej ${ }^{40}$, prawdopodobnie rozwiązanie rozbiorowe. $Z$ tego Stanisław August nie zdawał sobie sprawy, ale odpowiedź na pytanie, po co tłumaczył omówione przesłanie do Katarzyny, nie rysuje się jasno. Być może fiasko konfederackich zamysłów „Rady Patriotycznej" skłoniło go do sprawdzenia, czy nie przekonało ono Katarzyny II do zmiany stanowiska. List imperatorowej zamykał sprawę.

Zarazem kończył serię przekładów, których ewentualne rozpowszechnienie pokazałoby społeczeństwu, że król w pełni podzielał jego poglądy, że tak samo jak ono walczył o „wiarę" i „wolność”, że zatem nie był agentem Rosji, lecz w pełni zasługującym na szacunek i zaufanie Polaków ich przywódcą. To, że walka monarchy nie przynosiła upragnionych efektów, wynikało z nieustępliwości Rosji, która pewna swej militarnej przewagi odrzucała możliwość politycznych kompromisów.

Drugą serię tłumaczonej na język polski korespondencji Stanisława Augusta z Katarzyną II rozpoczynało pismo z 1 X 1770 r. Król podnosił w nim wielką krzywdę, jakiej doświadczali Czartoryscy, których dobra były od lipca tego roku zasekwestrowane, apelował o położenie kresu uciskowi swych ministrów, przekonywał, jak bardzo krzywdzące było pomawianie starych książąt o antyrosyjską postawę, wreszcie upominał się o niesłuszne oskarżanie jego samego o nie dość energiczną walkę z szerzącą się na południowo-wschodnim krańcu kraju zarazą ${ }^{41}$. Można przypuszczać, że przekład tego listu miał świadczyć o tym, że król nie opuścił w potrzebie ciemiężonych przez rosyjskie wojska polskich przywódców.

${ }^{38}$ Ibid., k. 167v-168v.

${ }^{39}$ Katarzyna II do Stanisława Augusta, 31 III [11 IV] 1770 r., ibid., k. 173-174; wersja francuska w: СИРИО, вып. 97, Санкт-Петербург 1896, s. 50-53.

${ }^{40}$ N. Panin pisał do M. Wołkonskiego o zacieśnieniu współpracy z Prusami, o perspektywie nowych negocjacji międzynarodowych dotyczących Rzeczypospolitej, spowodowanych ingerencją w sprawy polskie Francji, a także o ewentualności detronizacji Stanisława Augusta, zob. N. Panin do M. Wołkonskiego, 20 [31] X, 4 [15] XII 1769 r., СИРИО, вып. 87, s. 517-518, 538-543. Dnia 12 [23] X 1769 r. Rosja i Prusy podpisały nowy traktat przymierza, druk: Fedor MarTENs, Recueil des traités et conventions conclus par la Russie avec les puissamces étrangères, t. 6, Saint-Pétersbourg 1883 , s. 48-64.

${ }^{41}$ Stanisław August do Katarzyny II, 1 X 1770 r., AKP, nr 226, k. 182-183v (minuta francuska); Bibl. Czart., sygn. 940b, s. 185-187 (francuska kopia); AKP, nr 226, k. 218-219v (przekład polski). 
Podobne cele upatrywałabym w tłumaczeniu listów z roku 1772, związanych już z realizacją rozbioru. W pierwszym z nich, z 29 IV 1772 r., król skarżył się na wykraczające ponad wszelką miarę zdzierstwa wojsk rosyjskich ograbiających wszystkich bez wyjątku obywateli Rzeczypospolitej ${ }^{42}$. W drugim, o miesiąc późniejszym, zamieszczonym nadto w królewskich pamiętnikach, monarcha donosił o zatamowaniu przez korpus generała Nikołaja Sałtykowa działalności Trybunału litewskiego, co groziło dezorganizacją aparatu sprawiedliwości i niebezpieczeństwem anarchii w kraju ${ }^{43}$. W obu wypadkach, podnosił monarcha, ambasador Kaspar von Saldern (następca M. Wołkonskiego) odmówił interwencji. Przełożona na język polski odpowiedź Katarzyny II nie dawała podstaw do nadziei. Winą za sytuację w Polsce imperatorowa obarczała „zamieszanie, które [...] niszczy naród [...], drażni interesa tych wszystkich potencyj, których stany mają się z nim znosić, i które grozi [...] wywróceniem tronu Waszej Królewskiej Mości”. Katarzyna pozwoliła sobie przy tym na pogardliwe słowa o polskim sądownictwie i panującym $\mathrm{w}$ nim bezprawiu, stwierdzając, że Trybunały rozpatrują miałkie interesa, a w dodatku „nie są [one] najczęściej decydowane, jak tylko przez influencyją duchów strony więcej lub mniej jedna drugę przewyższającej”. Nie poprzestając na tym, przypomniano królowi zerwanie Trybunału koronnego w 1749 r. z komentarzem, że „nie wynikła stąd żadna wielka szkodliwość, ani też wołano, że to jest niebezpieczeństwem dla kraju"44.

Ostatni chronologicznie list, który został przełożony na język polski, Stanisław August napisał do Katarzyny II 27 VI 1772 r. Apelował do imperatorowej, by nie dopuściła do rozbioru Rzeczypospolitej; miało jej to przynieść trwałą wdzięczność Polaków, a od króla „oddalić obelgę i niewinne krajowych klęsk wyrzucania” ${ }^{4}$.

List ten nie doczekał się odpowiedzi, nie znamy też motywów jego wysłania. Znów można jedynie suponować, że w obliczu realizowanego już rozbioru Stanisław August próbował gromadzić materiały, które w przyszłości mogłyby stanowić wobec narodu dowody, że szukał możliwości wyjścia z impasu i ratowania zarówno państwa, jak i jego obywateli.

W analizowanym tu zbiorze polskich tłumaczeń pominęłam list z 4 XI $1771 \mathrm{r}$., napisany nazajutrz po zamachu na Stanisława Augusta. Zamieszczony także w pamiętnikach list ten rozpoczynał się od słów nadziei autora, że skoro Bóg zachował go przy życiu, „chce tego, abym nie ustawał pracować około dobra ojczyzny”. Dalej król prosił, by Katarzyna II, „nie dając się pobudzić występkiem małej liczby osób do surowości przeciw narodowi polskiemu, [...] chciała przyprowadzić już do

\footnotetext{
${ }^{42}$ Stanisław August do Katarzyny II, 29 IV 1772 r., AKP, nr 226, k. 200-201v (minuta francuska); k. 203-204 (przekład polski).

${ }^{43}$ Stanisław August do Katarzyny II, 27 V 1772 r., ibid., k. 206-206v (minuta francuska); k. 207-208 (przekład polski); publikacja: Mémoires, s. 394.

${ }^{44}$ Katarzyna II do Stanisława Augusta, 12 [23] VI 1772 r., СИРИО, вып. 118, Санкт-Петербург 1904, s. 188-189; polski przekład w: AKP, nr 226, k. 211-212.

${ }^{45}$ AKP, nr 226, k. 213-213v, 216-216v (kopie sekretarskie w języku francuskim); k. 214-215 (przekład polski).
} 
skutku przychylne swoje zamysły mnie wiadome względem pryncypalnych punktów naszych interesów" ${ }^{\prime 4}$. W tym wypadku cel listu i jego przekładu znamy. Po zamachu monarcha doszedł do wniosku, że z jednej strony współczucie dla niego, $\mathrm{z}$ drugiej dyskredytujący konfederację barską zamach otwierały szansę na sformowanie rekonfederacji, więc i na uspokojenie kraju, nawet bez rosyjskich ustępstw. $\mathrm{Z}$ tym planem wiązały się powstające wówczas $\mathrm{w}$ kręgu władcy i pobudzające do aktywności pisma polityczne, na czele $\mathrm{z}$ anonimowo ogłoszonym przez Stanisława Augusta Suum cuique. Zarówno jednak reakcja na zamach Katarzyny II, jak i K. von Salderna zmusiły monarchę do rezygnacji z tych zamysłów ${ }^{47}$. Imperatorowa odpisała na list króla późno i niezwykle chłodno, podkreślając, że nie powinien ufać narodowi, który dopuścił się zbrodni. Ową odpowiedź król zamieścił w pamiętnikach. Przekładu polskiego zapewne nie sporządzi1 ${ }^{48}$. Finalizując rokowania rozbiorowe, Katarzyna II nie była już zainteresowana ani antybarską konfederacją, ani żadnym typem aktywności Polaków. Przeszkadzałyby w rozbiorowej pacyfikacji. Omówione tu polskie przekłady korespondencji pozostały w rękopisie w formie brulionów, politycznie nieprzydatne.

prof. dr hab. Zofia Zielinska

Instytut Historyczny

Uniwersytet Warszawski

e-mail: z.zielinska@uw.edu.pl

${ }^{46}$ Stanisław August do Katarzyny II, 4 XI 1771 r., ibid., k. 197 (kopia sekretarska); k. 196 (kopia dziewiętnastowieczna); wersja francuska, druk: Mémoires, s. 419; wersja polska: AKP, nr 226, k. $198-198 \mathrm{v}$.

${ }^{47}$ Postawę mocarstw rozbiorowych oraz iluzje polskich polityków w tym okresie przedstawia: W. KonopCzyŃsKi, Konfederacja barska, t. 2, s. 580-599.

${ }^{48}$ Katarzyna II do Stanisława Augusta, 19 [30]ХІ 1771 r., druk w: СИРИО, вып. 97, s. 467-468; Mémoires, s. 419. 


\section{POLNISCHE ÜBERSETZUNGEN DES BRIEFWECHSELS \\ VON STANISŁAW AUGUST MIT KATHARINA II. UND NIKITA PANIN AUS DEN JAHREN 1769-1772}

\section{Zusammenfassung}

Schlüsselwörter: Briefwechsel der Monarchen, polnische Übersetzungen, Konföderation von Bar, Czartoryski, polnische und russische Diplomatie, erste Teilung Polens

Von den Briefen, die Stanisław August mit Katharina II. und Nikita Panin in der Zeit der Konföderation von Bar wechselte, wurden einige in der königlichen Kanzlei ins Polnische übersetzt. Die Übersetzungen standen wahrscheinlich im Zusammenhang mit einer von Stanisław August und den Czartoryski vorbereiteten Propagandaoffensive, die die Bevölkerung davon überzeugen sollte, dass nicht der Monarch und die Führer der Familie Czartoryski hinter der politischen Gleichberechtigung der religiösen Dissidenten und der Entführung von Senatoren durch den Botschafter Repnin standen. Die übersetzten Schriften bewiesen, dass der König in dieser Hinsicht mit aller Macht dem russischen Vorgehen entgegengetreten war. Letztlich entschied sich Stanisław August wahrscheinlich dafür, die angefertigten Übersetzungen nicht weiter zu verbreiten und sie erst recht nicht zu publizieren. Der in vielen Bereichen und auch mit anderen Mitteln unternommene Versuch, den König und seine Onkel mit der revoltierenden Nation zu versöhnen, der zu einer Beruhigung im Land führen sollte, brachte keine Ergebnisse.

\section{THE POLISH TRANSLATIONS OF STANISŁAW AUGUST'S CORRESPONDENCE WITH CATHERINE II AND NIKITA PANIN FROM THE YEARS 1769-1772}

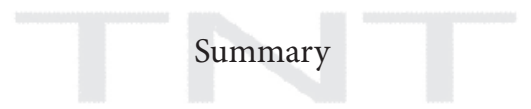

Key words: epistolography of monarchs, Polish translations, the Bar Confederation, the Czartoryski family, the Polish and Russian diplomacy, the first partition of the Rzeczpospolita

Among the letters which Stanisław August exchanged with Catherine II and Nikita Panin in the times of the Bar Confederation there are several ones which were translated into Polish. The translations were probably connected with the propaganda offensive prepared by Stanisław August and the Czartoryski family, aimed at convincing the society that the monarch and the leaders of the "Family" did not inspire the dissenters to strive for political equality, nor did they support the kidnapping of the senators perpetrated by Nikolai Repnin. The translated texts prove that the king opposed the Russian actions. Eventually, Stanisław August did not decide to promote the translated texts, still less - to publish them. The attempt to conciliate the king and his uncles with the rebellious nations, which was to appease the country, did not bear fruit. 